\title{
Establishment of new pastures free of ryegrass contamination
}

\author{
D.E. HUME and T.B. LYONS \\ AgResearch Grasslands, Private Bag 11008. Palmerston North, New Zealand
}

\begin{abstract}
Various pre-sowing management systems were applied from spring to early autumn, before drilling a new 'lolitrem-free' perennial ryegrass. These treatments aimed to evaluate the level of contamination over a range of ryegrass natural reseeding levels. Strips in the plots were left unsown or sown in prairie grass in order to assess the levels of natural reseeding. A late hay crop resulted in the largest contamination $(27 \%)$ of the establishing pasture. Lax grazing and spring barley (pasture direct drilled in autumn) resulted in approximately $3.5 \%$ contamination. Silage and early hay crops harvested before mid-December controlled most ryegrass seedheads, but further seedheads developed during summer. Control of seedheads in these treatments and the hard grazing treatment was difficult to achieve by grazing. A summer fallow, using a double spray with glyphosate (spray/fallow), successfully killed all existing vegetative plants and prevented natural reseeding, but seed present in the soil germinated to produce seedlings in autumn. Contamination levels in hay, silage, hard grazing, and spray/fallow treatments were $0.9 \%$. Although the reseeding levels in this trial were generally very low, when comparisons are made with other data, every effort should be made to minimise seedhead development and ripening of seed during spring/summer.
\end{abstract}

Keywords Acremonium Iolii, grazing, Loliumperenne, natural reseeding, pasture establishment

\section{Introduction}

Now that high endophyte (Acremoniurn lolii) perennial ryegrass (Lolium perenne L.) pastures can be replaced with new perennial ryegrass cultivars that contain a selected lolitrem-free endophytic fungus (Fletcher $\boldsymbol{e t}$ al. 1992), management practices must ensure that the new ryegrass pasture is not contaminated with the previous, undesirable, endophytic ryegrass. The same applies when high endophyte ryegrass pastures are to be replaced by non-endophytic species such as cocksfoot, tall fescue or nil-endophyte ryegrass. Possible contamina- tion of new pasture may occur through survival of existing ryegrass in the pasture or through natural reseeding. Direct drilling with no herbicide, or band spraying with herbicides, will allow some survival of existing plants. The only suitable options for preparing a lolitrem-free pasture are therefore cultivation, or direct drilling after complete kill of the vegetation by herbicide.

Natural reseeding may potentially contaminate pastures. particularly with autumn sowings. Perennial ryegrass is not generally considered a 'weed' species, for it shows little seed dormancy and is a relatively short-lived seed (Chancellor 1978). However, studies in New Zealand have shown buried seed contents of 108969 perennial ryegrass seeds $/ \mathrm{m}^{2}$ (Suckling, unpublished data), while natural reseeding can occur in ryegrass pastures even where pasture management is designed to minimise reproductive development (L'Huillier \& Aislabie 1988).

This paper reports a study investigating the levels of ryegrass natural reseeding after various spring/summer managements. before establishing a lolitrem-free ryegrass pasture in autumn.

\section{Materials and Methods}

Sites

A sheep grazed, predominantly perennial ryegrass pasture at the Aorangi AgResearch farm, Manawatu, was used for the main experiment, and a smaller experiment used a farmer's late hay crop sited $2 \mathrm{~km} \mathrm{NE}$ of the Aorangi farm. The Aorangi pasture was $73 \%$ perennial ryegrass ( $92 \%$ of tillers endophyte infected), $17 \%$ other grass species and weeds (predominately Poa annua L.) and $10 \%$ white clover (Trifolium repens L.). Tiller populations were $6300 / \mathrm{m}^{2}$ for ryegrass and $7000 / \mathrm{m}^{2}$ for other grass species. The soil was a Kairanga fine sandy loam of moderate fertility (e.g. Olsen P 16). The late hay crop was $80 \%$ perennial ryegrass with $46 \%$ endophyte infection, and had been under cattle grazing.

\section{Treatments}

The Aorangi pasture was subjected to 8 treatments and the farmer's late hay crop one treatment over spring 
Table 1 Sequence of events for cach treatment (prior to drilling new pasture on 12 March 1992), expected reseeding level (5 = max) and measurements.

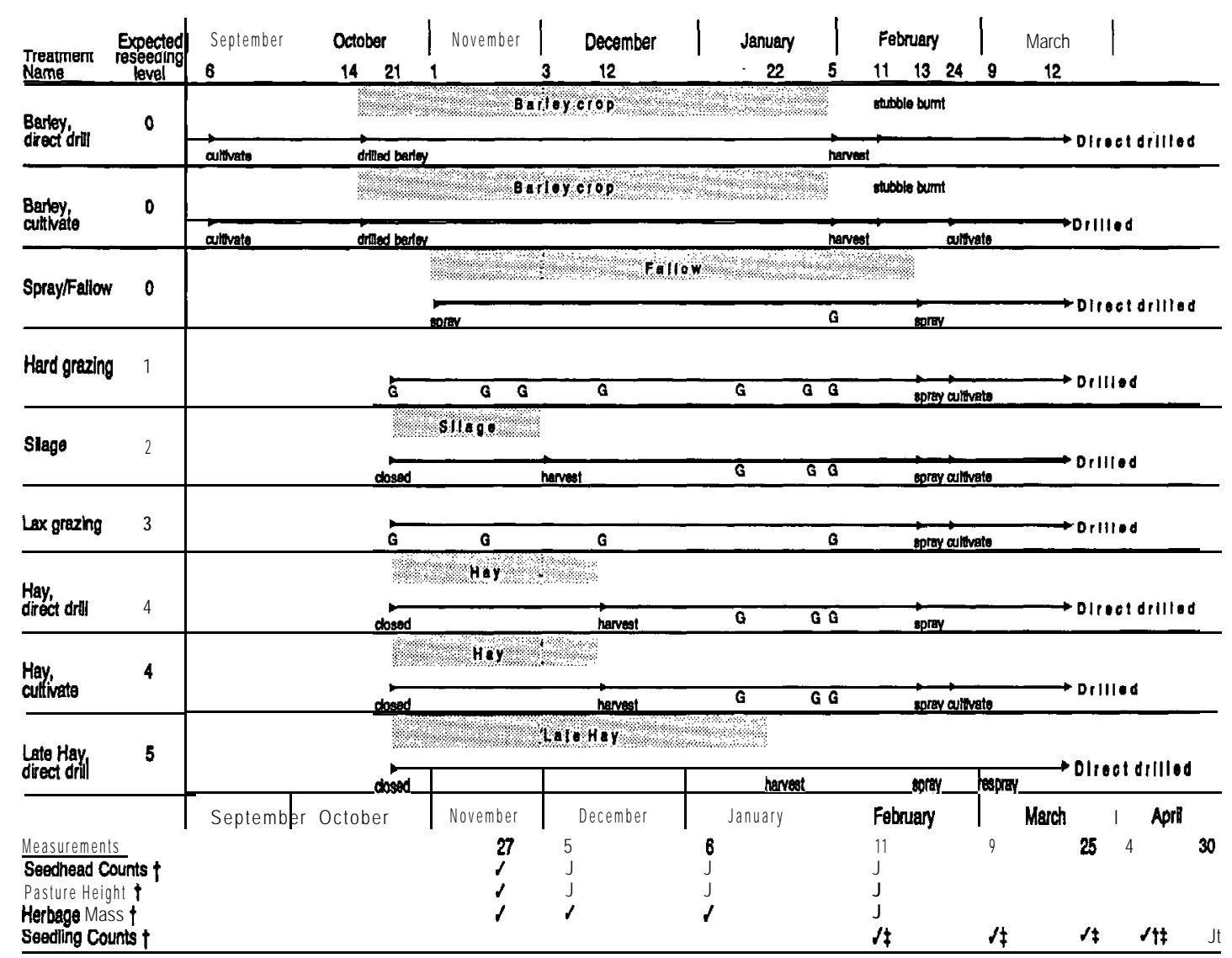

\section{-. Aorangl plots; $\$$ a late hay; $G$ s time of grazing}

1991/summer 1991-92, before sowing anew pasture in autumn 1992 (Table 1). Treatments were applied to produce a range of ryegrass natural reseeding levels. Aorangi plots ( $384 \mathrm{~m}^{2} / \mathrm{plot}$ ) were replicated 3 times and late hay plots $\left(32 \mathrm{~m}^{2} / \mathrm{plot}\right)$ replicated 5 times. During spring, pasture treatments (i.e. all treatments except barley crops) were moderately grazed with ewes (15/ha) and lambs (Aorangi) or cattle (late hay paddock) until late October. At this time the various treatments were applied.

Hard Grazing, Hay and Silage treatments were grazed (with sheep) frequently and hard, while Lax Grazing was infrequent and lax (refer to G's in Table 1). Spray/ Fallow plots were grazed once during the fallow Period to prevent strong weed growth from producing seed. Spy/Fallow plots were initially sprayed with 41 Roundup/ ha (360 g glyphosate/ $)$ with the next spraying in midFebruary (for all plots containing pasture) at a high rate of 51 Roundup/ha to kill couch (Agropyron repens (L.) Beauv.) and califomian thistles (Cirsium arvense (L.) Scop.) (Table 1). A respray (2 1/ha) of the Late Hay crop was required to kill ryegrass seedlings arising from natural reseeding.

AU plots were drilled in mid-March 1992 with perennial ryegrass $(20 \mathrm{~kg}$ viable $\mathrm{seed} / \mathrm{ha})$ infected with a lolitrem-free fungus and Grasslands Pitau white clover ( $3 \mathrm{~kg}$ viable seed/ha). To obtain an early assessment of possible contamination of the new pasture, a $4 \boldsymbol{m}$ wide strip in each Aorangi plot was drilled with Grasslands Matua prairie grass (Bromus willdenowii Kunth) (15 kg viable seed/ha) and Pitau white clover ( $3 \mathrm{~kg} / \mathrm{ha})$, instead of ryegrass and Pitau. In the Late Hay paddock. a $2 \mathrm{~m}$ wide strip in each plot was left unsown.

\section{Measurements}

Pasture measurements were taken from late November 1991 until April 1992 (Table 1). At Aorangi, seedheads/ $\mathrm{m}^{2}$ (4 $\times 0.25 \mathrm{~m}^{2} / \mathrm{plot}$ ), pasture height (20 rising plate readings/plot) and herbage mass (20 capacitance probe readings/plot) were assessed 4 times. Ryegrass seedlings $/ \mathrm{m}^{*}$ arising from natural reseeding were assessed 
twice at Aorangi $\left(10 \times 0.25 \mathrm{~m}^{2} / \mathrm{plot}\right)$ and 4 times for the Late Hay crop ( $\left.4 \times 0.1 \mathrm{~m}^{2} / \mathrm{plot}\right)$, in the areas sown in Matua and the unsown areas, at each site respectively. Buriedryegrass seed was assessed from $40 \times \mathrm{S} \mathbf{c m}^{2}$ cores in November 1991.

\section{Rainfall and temperature}

Temperature and rainfall records for the trial period were obtained from the Kairanga meterological station, sited on the Aorangi farm. $1 \mathrm{~km}$ from the main trial.

\section{Results and discussion}

\section{Effect of treatments on pasture and ryegrass seed- heads}

The pasture conservation treatments of Hay and Silage resulted in high herbage mass and seedhead numbers during late spring/early summer at Aorangi (Figure 1). Although seedhead numbers were over $1000 / \mathrm{m}^{2}$ none of these heads had reached anthesis (flowering) by the time of harvesting the hay or silage. In contrast, seedheads in the Late Hay treatment, approximately $700 / \mathrm{m}^{2}$, reached anthesis and set seed by the time the hay was harvested in late January. After harvesting the silage and hay at Aorangi. pasture mass and height were similar to that under Lax Grazing primarily due to the remaining cut stubble. Hard grazing of these treatments during summer reduced pasture mass and height to be similar to Hard Grazing plots by late summer. Despite many reproductive tillers being killed by spelling these treatments and then cutting for hay or silage, further seedheads developed at similar levels to those in Lax and Hard Grazing treatments (January 1992). Silage plots had more seedheads in February than hay plots (34 vs 12/ $\mathrm{m}^{2}$ ) but this was not significant.

Lax Grazing resulted in consistently higher herbage mass and height (mean, $2180 \mathrm{~kg}$ DM/ha, $7.5 \mathrm{~cm}$ ) than Hard Grazing (mean, $1440 \mathrm{~kg}$ DM/ha, $4.6 \mathrm{~cm})(P<0.001)$ (Figure 1). Seedhead numbers were usually higher in Lax $\left(105 / \mathrm{m}^{2}\right)$ than Hard Grazing plots $\left(73 / \mathrm{m}^{2}\right)$ but this did not reach statistical significance. When the sheep entered laxly grazed plots they were usually hungry and tended to eat the green seedheads. Repeated grazing of the Hard Grazing plots resulted in the length of seedheads shortening and some avoidance of the heads by the sheep. Similar problems may occur in practice on farms during late spring/early summer where achieving hard grazing may be very difficult on a paddock scale at a time when pasture growth rates are very high and exceed animal intakes. For example, in a similar trial, but on a larger scale in southern Hawkes Bay, the farmer completely removed seedheads by heavy mob stocking during late spring/early summer. However. further seed- heads developed during summer which were very difficult to control by grazing, similar to the difficulties under hard grazing at Aorangi (Hume unpublished data).

Although the Barley plots had undergone a full
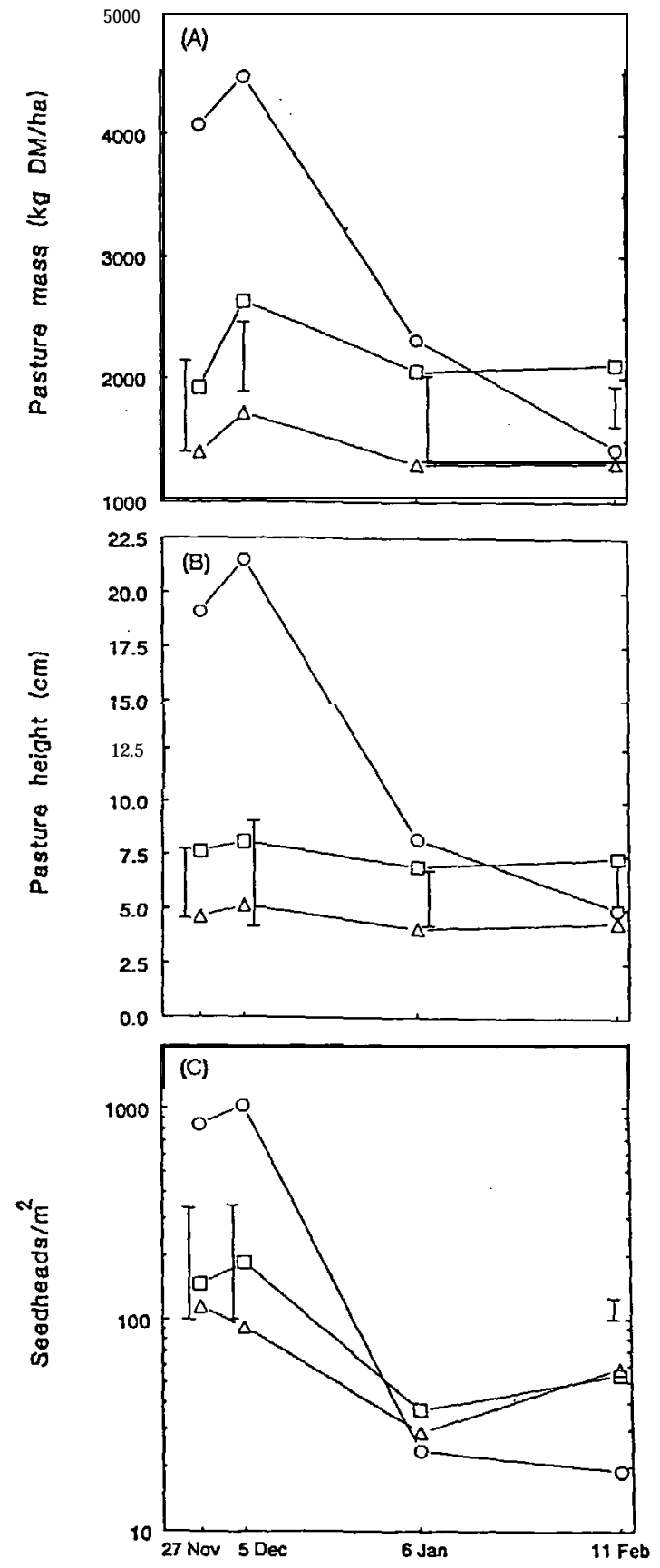

Flgure 1 Pasture mass (A), pasture height (B) and ryegrass seedhead numbers (C) during late 1991/early 1992 at Aorangi. Hay and Silage treatments (O), Lax Grazing ( $\square$ ), Hard Grazing (A), LSD values $(P<0.05)$ are shorn where differences in treatments are significant. 
cultivation over 5 weeks during September/early October. ryegrass plants still survived, flowered and set seed within the barley, despite the use of Glean plus Bromoxynil 40 (750 g/kg chlorsulfuron, $400 \mathrm{~g} / \mathbf{l}$ octanoate), a herbicide that can have detrimental effects onryegrass (Anon. 1990). Spray/Fallow plots had no ryegrass plants surviving or producing seed during late spring/summer.

In all treatments, spraying or cultivation before drilling new pasture in autumn had killed all the ryegrass tillers from the old pasture.

\section{Natural reseeding}

At the first seedling count at Aorangi in early April of naturally reseeded ryegrass, 3 weeks after drilling, Lax Grazing plots had the highest seedling numbers (13/ $\mathrm{m}^{2}$ ), Spray/Fallow plots the lowest $\left(\mathbf{0 . 7} / \mathrm{m}^{2}\right)$ and Barley/ Hay/Silage/Hard Grazing intermediate levels $\left(3 / \mathrm{m}^{2}\right)$ $(P<0.05)$. Seedling numbers had increased by the second count in late April with similar treatment differences to those occurring at the first count (Figure 2).

(a) Barley. The few ryegrass plants that grew and set seed in the barley crop produced viable seed and seedlings, although reseeding levels were lower than in other treatments (e.g. Barley Cultivate compared with Hard Grazing (cultivate)) (Figure 2a). Normally a full cultivation carried out when establishing barley would be expected to eliminate existing ryegrass plants. In a larger trial in southern Hawlces Bay, a similar problem occurred with Survival of ryegrass in summer fallowed plots, wherepasture wasploughedtoashallowdepthon a stony soil. Such problems may indicate that a herbicide should be used to ensure a completekill of ryegrass before establishment.

Greater seedling size in Barley Direct Drill plots, indicated that seedlings had germinated 2-3 weeks before seedlings in other treatments (Figure 2b). The early seedlings would have been killed by cultivation in the Barley Cultivate treatment.

(b) Spray/Fallow. Despite the complete removal of ryegrass from these plots, eliminating ryegrass seed production during the 1991/92 season, some seedlings appeared (Figure 2a). These seedlings could have originated from (a) seed from the previous spring/summer (1990/91) and/or (b) seed in hay fed to cattle on this area over winter, before starting the trial. Results of the buried seed samples taken in November showed no ryegrass seed in the soil. The total area taken in 40 cores (i.e. $0.02 \mathbf{m}^{2}$ ) was inadequate to detect the very low seed levels that were evident as reseeding in Spray/Fallow plots (1.4 seedlings $\left./ \mathrm{m}^{2}\right)$. Seed certification standards require at least 2 years between successive ryegrass
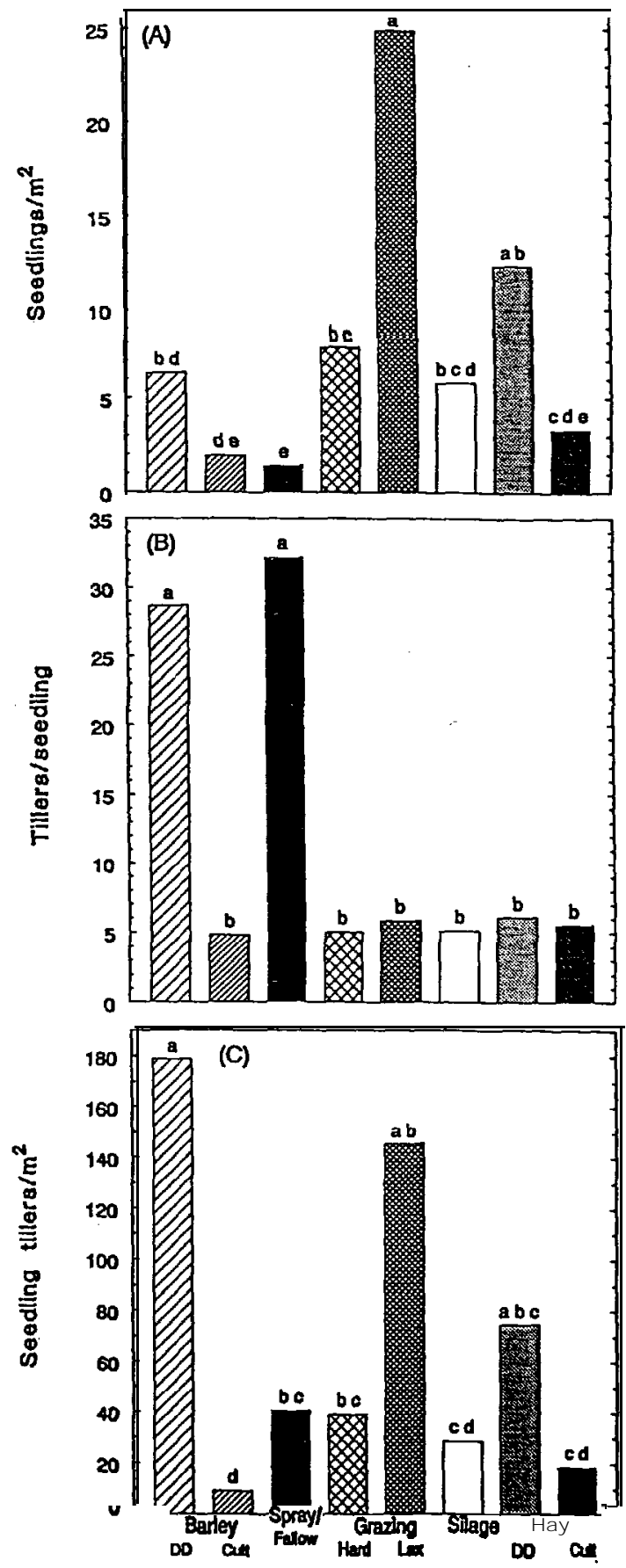

Figure 2 Numbers (A), size (B) and tiller populations (C) of ryegrass seedlings emerging from natural reseeding, as measured in Matua sown areas et Aorangi in late April 1992. DD = direct drilled, Cult $\approx$ cultivated prior to sowing. Means accompanied by the same letter are not different $(P>0.05$, for log transformed data). 
seed crops to prevent contamination (Anon. 1991). Implications of this forcompleteremoval of natural reseeding (ryegrass seed in the soil) is that paddocks may have to undergo two years of cropping before sowing new pasture.

Seedlings in Spray/Fallow plots were about 6 times larger (tillers/seedling) than those in other treatments (except Barley Direct Drill), indicating that they had germinated 2-3 weeks earlier (Figure 2b).

(c) Silage, Hay, Lax and Hard Grazing. Despite the large numbers of seedheads that werekilledby conserving hay and silage, the aftermath seedbeads that developed over the summer resulted in similar reseeding to Hard Grazing. Lax Crazing, which increased number of seedheads only slightly, gave much greater seedling numbers. It was observed under lax grazing that more seedheads had dried off with mature seed than under hard frequent grazing in the other treatments. The amount of ripe seed present when the plots were cultivated ${ }_{\mathrm{m}}$ direct drilled appeared to be of equal importance to the numbers of seedheads. Natural reseeded seedlings were of similar size to sown seedlings (30 April, 5.4 tillers/seedling) in these treatments (Figure 2b).

(d) Late Hay. Seedling numbers were very high in this treatment. Before the first Roundup spray (11 February) there were 9170 seedlings $/ \mathrm{m}^{2}$ with a further $3470 / \mathrm{m}^{2}$ recorded on 9 March immediately before the second Roundup spray. After drilling the new pasture, a further 340 seedlings $/ \mathrm{m}^{2}$ were recorded. Seedling size was similar for sown and natural reseeded seedlings. Such high levels of natural reseeding are expected with a late hay crop which allowed full reproductive development and seed set over late spring/early summer, the main period of reproductive development in ryegrass.

(e) Cultivation versus direct drilling. Full cultivation of plots in preparation for sowing the new pasture, in comparison with direct drilling. appeared to have reduced the numbers of seedlings (i.e. Barley and Early Hay treatments, Figure 2a). presumably by the burial of seeds on the surface to depths where they did not germinate, м germinated and did not successfully emerge. Cultivation also affected seedling size in barley plots, with seedlings in direct drilled plots being seven times larger than in cultivated plots. Full cultivation therefore appears to be a technique to reduce seedling numbers and size.

\section{Rainfall and temperatures}

From late spring to mid-autumn, mean air temperatures $\left(13.4^{\circ} \mathrm{C}\right)$ were $2^{\circ} \mathrm{C}$ lower than the 20 year-average $\left(15.4^{\circ} \mathrm{C}\right.$ ).
Summer and early autumn were wet, with $68 \%$ more rain $(420 \mathrm{~mm})$ than average $(250 \mathrm{~mm})$. The influence of these cool wet conditions on seedhead formation, seed maturity and reseeding is unknown.

\section{Importance of reseeding levels}

When seedling numbers and size are combined, the overall levels of ryegrass natural reseeding can be judged from seedling tillers/m* (Figure $2 \mathrm{c}$ ). In comparison with ryegrass seedlings in sown areas, these populations are relatively minor. Sown ryegrass seedlings were $830 / \mathrm{m}^{2}, 5.4$ tillers/seedling and 4480 tillers $/ \mathrm{m}^{*}$. Reseeding in Barley Direct Drill plots, the highest level at Aorangi, represented a contamination of $4 \%$ while Barley Cultivate plots. lowest level, was a contamination of $0.2 \%$. In the Late Hay plots, natural reseeding representedcontaminationof $\mathbf{2 7 \%}$, and would have been considerably higher if drilling had been earlier.

No data are available to suggest what levels of contamination (i.e. amount of wild type endophyte present in a lolitrem-free sward) will affect animals in terms of ryegrass staggers and animal liveweight gains. In the present study, contamination from a late hay crop before establishing a lolitrem-free pasture, was considered unacceptably high.

Although reseeding in the other treatments was very low, it should not be dismissed as unimportant, as the treatments applied in this trial period may have different effects in other years, districts. or under different stocking systems. FM example, a reseeding trial under dairying conditions at Ruakura (L'Huillier \& Aislabie 1988) showed levels of seedheads and seedlings considerably higher than in the present trial. Their harshest treatment was 'hard grazing with topping' (1500 kg DM/ha pasture residual with topping to $5 \mathrm{~cm}$ after grazing. grazing rotations of 4 weeks in spring and 5 weeks in summer), resulting in 363 seedheads $/ \mathbf{m}^{2}$ and 240 seedlings $/ \mathbf{m}^{2}$. Their 'complete reseeding' treatment, equivalent to the Late Hay treatment (no grazing mid-October to midJanuary), gave 2149 seedheads $/ \mathrm{m}^{2}$ and 11900 seedlings/ $\mathbf{m}^{\mathbf{2}}$. If compared with sown ryegrass seedling populations (e.g. 800 seedlings $/ \mathbf{m}^{2}$ ), contamination would be at least $23 \%$ if a new pasture was direct drilled in autumn.

\section{Conclusions}

Until substantial evidence is available to indicate what levels of wild type eudophyte can be present in a lolitrem-free ryegrass pasture without affecting animal performance, all steps should be taken tominimise seedhead production, and most importantly, ripening of seed during summer. Winter/spring cropping (ensuring that all ryegrass is killed prior to drilling crop), hard grazing, 
summer fallow (spray/fallow or cultivated) or early conservation (silage or early hay, followed by hard grazing), can minimise reseeding if applied correctly.

\section{ACKNOWLEDGEMENTS}

We thank the staff of the Aorangi research farm for assistance and T. Dahl for the use of his late hay crop. This project was funded through the Technologies for Business Growth programme, by Challenge Seeds Ltd, Foundation for Research Science and Technology, New Zealand Agriseeds Ltd. and New Zealand Pastoral Agriculture Research Institute Ltd.

\section{REFERENCES}

Anonymous 1990. New Zealand Agrichemical and Plant Protection Manual. 3rd edition, B. O'Connor (ed), Wham/Novasearch, Wellington/Manawatu. Anonymous 1991. Seed Certification X991-1992. Field and Laboratory Standards. Ministry of Agriculture and Fisheries Quality Management, Christchurch.

Chancellor, R. J. 1978. Grass seeds beneath pastures. In A.H. Charles \& R.J. Hagger (eds.), Changes in Sword Composition and Productivity. Occasional Symposium No. 10: pp. 147-150. British Grassland Society, Hurley.

Fletcher, L. R.; Popay, A. J.; Tapper, B. A. 1992 Evaluation of several lolitrem-free endophyte/ perennial ryegrass combinations. Proceedings of the NZ Grassland Association 53: 215-219.

L'Huillier, P. J.; Aislabie, D. W. 1988. Natural reseeding in perennial ryegrass/white clover dairy pastures. Proceedings of the NZ Grassland Association 49: 111-1 15. 